\title{
Re-reading Caste and Gender: A Study of the Rituals of Kodungallur Sri Kurumba Bhagavathy Temple of Kerala
}

\author{
Mr. Sudheesh S \\ Research Scholar, Department of History, \\ Nesamony Memorial Christian College, \\ Marthandam, Tamil Nadu, India
}

\author{
Ms. Athira Prakash \\ Assistant Professor, Department of English, \\ SVR NSS College Vazhoor, \\ Theerthapadapuram, Kerala, India
}

\begin{abstract}
every society has a set of cultural value systems, by which its members are socialized into a desirable code of conduct which clearly distinguishes what an individual is expected to do and what not. Such value systems later find expression in various rules and norms and are explained and expanded through social practices like rituals and rites. Hence social practices in the form of myths and rituals do not simply refer to private taste, but to assumptions by which certain groups exercise and maintain power over others. Those who manipulate and design the rituals, rites and myths will have definite set of objectives and they execute it and make them entrenched in the human psyche in such a way that the powerless majority take it as natural and universal, hence not to be questioned or changed. This often leads to social injustice, marginalisation and exclusion of the vulnerable group. The paper is an attempt to read the sexual and caste politics, not only in the way it is designed but also in the way it is received and got modified through ages.
\end{abstract}

Keyword: Gender, Caste, Sexual Politics, Cultural Hegemony, class, caste

\section{INTRODUCTION}

Ritual studies is not a school, nor is it a theory or a method; it is a multi- or interdisciplinary platform for the academic, critical, and systematic study of ritual.It initially combined the fields of religious studies, anthropology, liturgical studies, and theatre studies. Later it has got wider political and cultural implications as the impact of rituals and myths is very much get reflected in the way people think, live and behave themselves.
Every society has a set of cultural value systems, by which its members are socialised into a desirable code of conduct which clearly distinguishes what an individual is expected to do and what not. Such value systems later find full fledged expression in various rules and norms and are explained and expanded through rituals and rites. Ritual is a more or less repeatable sequence of action units which, take on a symbolic dimension through formalization, stylization, and their situation in place and time. On the one hand, individuals and groups express their ideas and ideals, their mentalities and identities through these rituals, on the other hand the rituals shape, foster, and transform these ideas, mentalities and identities. The members of the upper strata of power hierarchy manipulate and design the rituals, rites and myths in order to suit their needs and preserve their power in such a way that the powerless majority take it as natural and universal, hence not to be questioned or changed. This often leads to social injustice, marginalisation and exclusion of the vulnerable group. The study focuses on the select rituals and rites of the temple mainly that of Bharani festival.

According to tradition, Sage Parasurama is said to have established Temples by raging the land of Kerala from Sea throwing his battle axe. He further built 108 temples in this region. Kerala Mahatmyam, a great book which deals with history of Kerala discusses that God Vishnu instructed Parasurama to establish numerous temples all over the region and to install different deities in them. According to another belief, the temple was built by Charan Chenguttavan, the brother of Elango Adigal who wrote the monumental work 'Shilappadikaram' residing at Kodungallur. 
However,the beginning of the Kodungallur temple is shrouded in antiquity. It is also believed that the temple was built to commemorate the martyrdom of Kannakis in the Sangam age. During the reign of Kulasekhara dynasty, Kodungallur was the capital of Kerala and one of the most important parts of the region. There is a good number of records available describing the unique rituals and rites of the temple, but there are hardly any work detailing the hidden agenda behind every ritual and there by exposing the class, caste and gender politics associated with it.

The temple is dedicated to goddess Bhadarakali and is fondly called as "Kodungallooramma" by devotees. It is one of the famous devi temples in Kerala. This city was also the capital of Cheraman Perumals, during the 7th century. During the rule of the Chera dynasty, Kodungallur was a great emporium of trade even before the dawn of Christian era. It was the centre of trade and commerce with foreigners like Jews, Phoenicians, Greeks, Romans and Arabs. It had direct trade links with countries like Egypt, Syria and the Middle East countries. The city used to export a large quantity of spices, like pepper, to different countries. Muziris is a well-known port city in Kodungallur. Neither the history of Kodungallur nor the study of rituals of Kodungallur temple would be complete and meaningful without mentioning the socio political and cultural changes emerged in the society.

Though Prof Elamkulam made the first attempt to unravel the major issues related to Kerala History, nothing he mentioned about common people, settlements, markets, network of sacred groves, family systems, customs and manners of the dark periods from $300 \mathrm{AD}$ to $800 \mathrm{AD}$.he confesses that there is no valid evidences found to do it. Later it was MGS who started investigation and analysed history of Kerala. These two great historians inspired N M Namboothiri to explore history of Kerala based on toponymycal data. It was taken up to understand the social and cultural history of Malayala Naatu and these studies are generally termed as Janapadanam or settlement studies.

It was in the $3^{\text {rd }}$ cetury BC that the Budhist and Jains reached kerala. Even though there is no unanimous opinion among historians regarding the exact date of Brahmin migration to Kerala many considered it as the continuation $f$ the Budhist Jains settlement. According to K.P Padmanabha Menon, the Brahmins reached in 3rd C A.D, where as William Logan opined that it was in 8th C A.D. The modern historians opined that one cannot assume that they have come to Kerala as a big settlement group rather than they came as small groups in different times and settled in various places. There are references of Brahmins in Kerala in Sangam literature.

Brahmins had known about Kerala through the trade and commerce of those days between North and South India. Once they reached to Kerala, Brahminism could not flourish like the North Indian Brahmanism/Vedic tradition in Kerala. In pazhamtamil literature, they are mentioned as Anthanar and their main duty was to conduct yagas and other Vedic rituals for Cheras.6 Brahmins gave ideological support and justification of the administration of the Chera kings. As remuneration, they got land and other valuable things from the king. Then the Brahmins became a strong socio economic power. The other classes such as Panar (Bards of Nayar community), Vedar (local tribe) and Kuravar (local tribe) who were getting help from the king were sidelined and downgraded their position to the lower strata of society.

Jains and the Buddhists in Kerala were basically traders. When the land trade stagnated, the Jain centers where the temples are kept alive by the donations from the caravans, lost their prosperity. Gradually the temples must have deserted and some of them were taken over by the Brahmins and turned them to Hindu temples. Similarly, in the Buddhist centers on the sea shore which were obviously the offshoot of the trade with Sri Lanka seemed to have suffered from the cola imperial wars of $11^{\text {th }} 12^{\text {th }}$ and $13^{\text {th }}$ century .Moreover, the Brahmin settlement in Kerala and the conflicts within the Buddhist and Jain philosophy also gave rise to the decline of these two creeds.

The Kodungallur Bharani festival is one of the most unique rituals in Kerala. For years, it was one of the only temples that allowed lower castes entry into the temple premises. This was one of the earliest temple festivals with a predominantly lower caste crowd including vannans, mannans and pulayas. During the kavu teendal ceremony of the festival, devotees from the lower caste communities sing songs composed of abusive terms, expletives and explicit reference to female sexual organs. V T Induchoodan has rightly pointed out this ritual as an earlier form of dalit performance. 
During the kavu teendal ceremony of the festival, devotees from the lower caste communities were allowed to participate. The temple receives an additional act of pollution by the touch of the Palakkal Velan (a desecrating priest), and devotees of most levels of society throw offerings over the walls simultaneously. At the north door to the shrine building a lamp is lit to represent the victory of Bhadrakali over Darukan.

The next day, Karttika, the temple is swept out, purified, and reconsecrated by Nambudri priests, who in this way reestablish liturgical control. They perform pujas every morning of the following week behind closed doors. On the seventh day, Minam Puyam, the doors are Kodugalloor reopened. The interpretations of the closing of the temple for a week vary, but they hinge on the state of the goddess.

Bhagavati celebration at an Araya Bhagavati temple indicates that the doors are closed because the goddess needs to "rest" after the excitement of the festival. She is said to become very agitated during the festival. The return to the daily Brahmin-led pujds to calm the goddess is preceded by a week of recuperation or denial.

The most controversial and widely discussed ritual of Bharani has been the singing of obscene sexual songs and slogans by the pilgrims. These describe the sexual organs of the male and female and narrate the sexual act in the most naked manner. They start singing all along the way and in the temple premises, though not inside the temple [srikovil]. There are usually men and women, of all ages, among the pilgrims, though the female sex may be less in proportion. I have not come across any records which may show that there had been any sexual orgy. The songs may or may not have religious significance. Some of them may be about Kali; others may be just simple sex. (V.T Induchudan)

Bharani festival was born out of a tactical move on the part of the Hindus in the area to usurp Buddhist property. Some of the narratives posit Kannagi as the primary deity of the Kodungallor temple. Kannagi or the cult of the Goddess Pattini has been long associated with Buddhism. Sadasivan states in his book that the Chera king Chenkuttavan built a structure to consecrate her memory in the presence of Gajabahu, the king of Ceylon. This could be the Kodungalloor Bhagavathi temple. Kannagi is the heroine of the famous Cilappatikaram. Legend has it that Kannagi and her husband Kovalan, lived in Madurai. Kovalan spent most of his time with a local courtesan. However, after he lost all his money, Kovalan returned to Kannagi and asked her for help. Kannagi, the virtuous wife, gave him her anklet to sell. Kovalan took this anklet to Madurai to sell it. At the same time, the queen's anklet went missing and Kovalan was charged with robbery and put to death. When Kovalan did not return, Kannagi went looking for him. Her search brought her to Madurai, where she learnt of her husband's fate. Furious, Kannagi went to the royal palace and showed the court the other anklet in the pair and proved her husband's innocence. In her grief, Kannagi, the virgin widow, cursed the city by ripping her breast and flinging it at the city and the city went up in

The bharanipaatu has two distinct strands - the devi stotram and the theripaatu. The devi stotram, the more widely understood strand, praises the kindness and glory of the goddess. Some of these songs deal with the various conquests of the Goddess and others deal with her origin. The theripaatu, or songs with explicit sexual content, on the other hand, praise every aspect of the Goddess, especially her sexuality. Any representation is a political activity as it gives legitimacy and visibility to the subject. What is dangerous with representation is that it can not only reveal what the subject may be in reality but it is also capable of distorting the very essence of the subject itself.

When the bharnipattu is sung for goddees, the songs are meant to arouse her and to provide an outlet to the young widow who was unable to consummate the marriage with her husband. believed that the theripaatu are not sung for a young, sexually unfulfilled widow but instead were meant for Nalachan - a friend of Kannagi and Kovalan. Once, Kannagi and Kovalan were travelling, they stopped enroute at Nalachan's place. In the middle of the night, while Kovalan was asleep, Nalachan propositioned Kannagi. Kannagi, who knew the duties she had to fulfil as an incarnation of the Goddess, asked Nalachan to come to Kodungallur at a certain time, where she promised she would satiate his desire. Much later, after Kannagi had burned down Madurai and arrived at Kodungallur, Nalachan came to claim what he had been promised. It is also believed that Kannagi (the Goddess at Kodungallur now) transformed Nalachan into a stone and rooted 
him to one spot. However, every year to keep her promise, she called upon her devotees to sing songs to satiate Nalachan's desire.

The theripaatu changes and questions the very notion of what constitutes the language of the sacred. It democratizes it and in doing so, it makes the space of the sacred a more accessible space. It is within the field of the theripaatu, lies the greatest possibility for subversion, a gendered, caste based subversion The speech though incited by religion and driven by devotion, may not even be born out of a conscious political need to subvert the sexual mores of Malayali society, but by the mere act of publicly making a spectacle of that which is considered most private, the devotees pose a resistance to Kerala's carefully regulated system of sexual speech.

Even though the Bharaippattu is factored into the existing systems of power, a discourse sanctioned by 'mainstream Hinduism', the growing discomfort of both the upper castes and the social activists and feminists with this phenomenon, is a signal that this discourse has long outlived its utility. Many scholars suggest that the Bharanippattu began when lower castes were instigated by the Brahmin Namboodiris to sing lewd songs that would drive out the Buddhist monks from Kodungallur. Whatever may be the reason, it is sung out of great devotion for the goddess. They are not sung to denigrate the goddess, but sung out of devotion and respect. Even though the branding of these songs as 'theripaatu' embodies the moral standards of the upper castes, who are not part of the festival, it is foolishly innocent to consider that women are staking claim to the freedom of sexual. Bharanippaatu can never be considered as a discourse on sex and sexuality. It is not because Bharanippattu lies outside Brahmanical systems of power nor it does disturb the Brahmanical and puritanical Hindu regimes.

The strategic manipulation of the designers of any ritual would be a privileged group who want to preserve their power and succeed in making the powerless and vulnerable group feel it universal and natural. So that there arise no scope for interrogating or changing the system as these rituals along with a manipulated value system are deeply entrenched in human psyche. But the cultural and historical context of Kodungallur kavutheendal gives the two possibilities. One it is manipulated by the upper class itself as a result of their awareness that the powerful majority of the native lower class people might cause a threat to them unless and until they are given some cultural break. The nomenclature kavutheendal, not kavu pravesham or Kavupookal shows the upper caste people's innate incapacity to irradicate the caste demarcating lines. Moreover it is the strategic and tactful move of the so called Hindu class to get back their place of worship which was occupied by the Budhist with the help of the lower caste people of place. The second possibility is that it is designed by the lower class themselves as a resistance to the Aryanisation of the temple rites and rituals.

Sexual politics could be explicitly read in the bharanippaatu by analyzing the manner in which the sexuality of women is being repesented. The question why the songs in Malayalam dialect explaining the sexual organs of a woman are known as therippaattu through ages unravels the politics which gets linguistic and cultural dimension.

Even within the class and caste there remains a strong sexual politics when patriarchy decides and defines the woman and her sexuality. Apart from provoking the academicians to explore the complex web of caste and gender, this ritual unravels the resistance to the dominant social religious behavioral codes. This ritual problematizes what is profane and sacred.

\section{Bibliography}

1. Aiyya. V Nagam. Travancore State Manual Vol.I, Pt.2: Chapter 6 -Trivandrum: The Govt. Press, 1906.Print. Travancore State Manual Vol.III, Trivandrum: The Govt.Press, 1906, Print

2. A. Sreedhara Menon, A survey of Kerala History, Chennai: S. Viswanathan Publishers, 1967. Print. Cultural Heritage of Kerala Kottayam: DC Books, 2008. Print.

3. Dr. C. Adarsh. Vibhavanakal Vinimayangal: Kodungalloorinte Vyavaharika bhoomishastram (Malayalam) Edappal: Vallathol Vidyapeed, 2013, Print.

4. Elamkulam P. N. Kunjan Pillai, Studies in Kerala History, Kottayam: National Book Stall, 1970. Print.

5. V. T Induchoodan. The Secret Chamber: A Historical, Anthropological \& Philosophical Study of the Kodungallur Temple. Trissur: Cochin Dewaswam Board, 1969.Print. 
International Journal of Trend in Scientific Research and Development (IJTSRD) ISSN: 2456-6470

6. Narayan.M G S. Aspects of Anyanisation in Kerala. Trivandrum: 1973.Cultural Symbiosis in Kerala. Kerala: Trivandrum: Govt Press1976.Print. Perumals of Kerala: Political and Social Condition of Kerala Under the Cera Perumals of Makotai (A.D 800- A.D 1124), Kerala: Xavier press, 1996.Print.

7. Narayan, M. G. S \& Veluthat, Kesavan. The Temple in South Indian, Symposia on the socio
Economic Role of Religious Institutions in India. Kerala: Govt Press.1981. Print.

8. Veluthat, Kesavan. Brahman Settlements In Kerala, Calicut: Cosmo, 1978.Print.

9. William Logan. Malabar Manual. New Delhi: Asian Educational Service, 1951. Print.

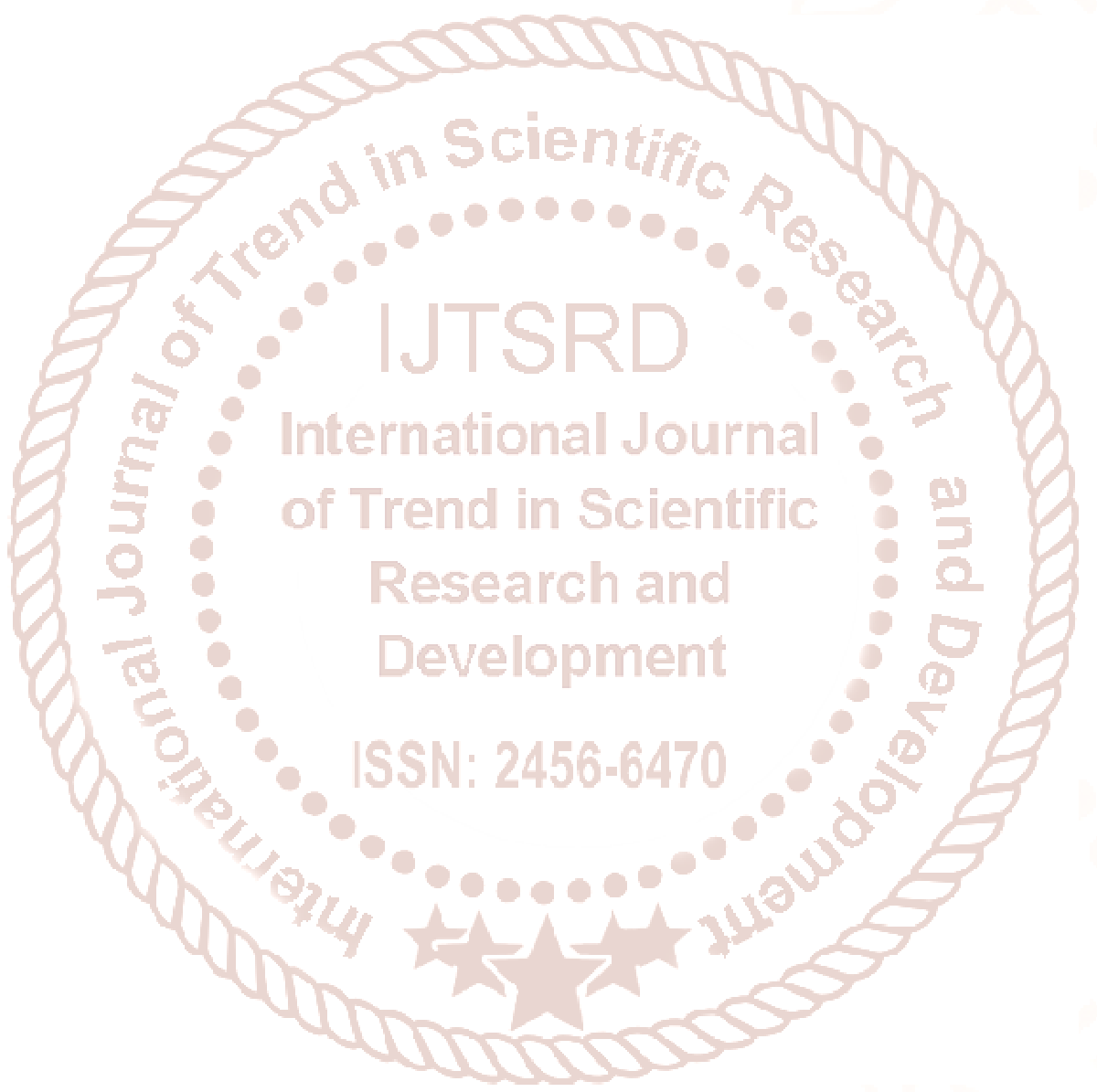

